\title{
HOW CONSUMERS' INFLATION EXPECTATIONS RESPOND TO EXPLOSIVE PERIODS OF FOOD AND ENERGY PRICES: EVIDENCE FOR EUROPEAN UNION COUNTRIES
}

\section{Aytül Ganioğlua}

\begin{abstract}
In this study, using the recent recursive unit root tests proposed by Phillips et al. (2015), we identify and date-stamp periods where food and energy prices deviate explosively relative to other prices in the economy and analyse the implications in terms of anchoring inflation expectations. During the period from January 2003 to July 2018, we have detected the existence of such periods for 17 out of 27 EU countries. Identifying these explosive periods is particularly important since evidence reveals that consumers change, i.e., revise their inflation expectations during periods when headline consumer prices deviate explosively from core prices. Furthermore, it is realized that consumers take macroeconomic variables into account as well as past inflation when forming inflation expectations in both normal and explosive periods. On the other hand, there are particular differences among groups of countries while adjusting their inflation expectations during explosive phases. A common feature for all the countries is that during explosive periods, consumers change and update their inflation expectations on the basis of information coming from the interest rate. More specifically, consumers in all the countries perceive a higher current interest rate as an indication of higher future inflation, leading to higher inflation expectations in explosive periods. A particularly important policy implication of these findings is that periods of explosive deviations in headline prices from core prices should be monitored closely while designing policies to anchor inflation expectations.
\end{abstract}

Keywords: Explosive behaviour, food and energy prices, inflation expectations, generalized sup ADF test, inflation, core inflation

JEL Classification: C50, E31

a Structural Economic Research Department, Central Bank of the Republic of Turkey, İstiklal Cad. No:10 Ulus, Ankara, Turkey

Email: aytul.ganioglu@tcmb.gov.tr

The views expressed in this paper are those of the author and do not reflect the official views of the Central Bank of the Republic of Turkey. All errors are the author's own. Acknowledgments: I am very grateful to Utku Özmen and Eda Gülşen for providing me with invaluable comments and remarks, which have greatly improved the paper. 


\section{Introduction}

It is known that food and energy prices are the most volatile sub-components of Consumer Price Index (CPI) inflation, especially displaying the highest average inflation over the past three decades (Parker, 2017). Although large volatilities in food and energy prices are usually expected to correct themselves over the short run, they may create a persistent divergence between headline and core inflation.

Given that monetary policymakers are responsible for maintaining overall price stability and aim to achieve low and stable headline inflation in the long run, they need a reliable predictor of future inflation. Nonetheless, core inflation may not be a good predictor of future inflation during periods when the divergence between headline and core inflation becomes persistent, not a transitory one, due to explosive increases in food and energy prices. Such persistent divergence also activates the debate whether monetary policy should focus on core versus headline inflation (Thornton, 2011; Bullard, 2011).

Accordingly, persistent divergence between headline and core inflation deserves close attention since anchoring inflation expectations can be difficult for policymakers when headline inflation diverges from core inflation repeatedly, not in a transitory manner. Such a case is explored for the US economy over the period 1982-2010 by Arora et al. (2013). They initially identify episodes where headline inflation deviates from core inflation ${ }^{1}$ in an explosive manner in the US economy and then question the implications for consumer inflation expectations. On the basis of their findings, consumers set their inflation expectations differently when food and energy prices rise sharply relative to other prices in the economy. In other words, consumers may read large increases in food and energy prices as signals of upcoming inflation and thereby revise their inflation expectations.

Our study has been motivated by the findings put forward by Arora et al. (2013) for the US economy. Quantifying how consumers' inflation expectations change when food and energy prices have deviated explosively relative to the prices of other goods comprises the main objective of the current study. To that purpose, we address this issue for a sample of 27 European countries ${ }^{2}$ from January 2003 to July 2018.

1 Prices excluding food and energy.

2 Belgium, Bulgaria, Czech Republic, Denmark, Germany, Estonia, Ireland, Greece, Spain, France, Italy, Cyprus, Latvia, Lithuania, Luxembourg, Hungary, Malta, the Netherlands, Austria, Poland, Portugal, Romania, Slovenia, Slovakia, Finland, Sweden and the United Kingdom. As we will explain later in Section 2, the analysis is performed for 27 European Union countries excluding Croatia due to data availability restrictions. 
In this study, we initially aim to identify periods when headline inflation has deviated explosively from core inflation ${ }^{3}$ for these countries. In order to detect the explosive periods, among various econometric test procedures proposed in the literature, we decided to rely on a recent methodology developed by Phillips et al. (2015), which produces novel evidence on the testing and dating of multiple bubbles in data. Along with this methodology, we basically search for explosiveness as a statistical property of a time series through recursive right-tailed Augmented Dickey-Fuller (ADF) unit root tests. Additionally, this innovative technique delivers an ex-ante dating algorithm relying on a recursive backward regression technique, whereby one can time-stamp the origination and termination dates of the explosiveness.

In order to address our ultimate concern of getting insights about the impacts of explosive behaviour of food and energy prices on inflation expectations, we followed the framework proposed by Arora et al. (2013). In compliance with the inflation expectations specification proposed by Mankiw et al. (2004), we include unemployment rate and interest rate as macroeconomic variables to get a notion of how inflation expectations may respond.

To the best of our knowledge, this article will be the first to search for explosive behaviour in food and energy prices relative to the prices of other goods for a large set of countries and thereby gets implications on consumers' inflation expectations. Our findings reveal that consumers pay less attention to past inflation in forming their future inflation expectations when they observe explosive deviations in food and energy prices relative to other prices in the economy in the group of countries comprising Bulgaria, the Czech Republic, Hungary, Poland, Romania, Slovakia, Slovenia, Estonia, Latvia and Lithuania. In the other group of countries, comprising Germany, France, Luxembourg, Austria, Finland, Sweden and the United Kingdom, consumers do not adjust their expectations on the basis of past inflation during explosive periods. They rely more on information coming from macroeconomic indicators such as unemployment rate and interest rate when forming inflation expectations during explosive periods. An even more important finding is that consumers' inflation expectations change during explosive periods in all the countries.

The results indicate that consumers in all the countries rely on information coming from interest rate when forming inflation expectations during normal and explosive periods. However, again there are particular differences in those impacts across the group of countries. The results indicate that consumers in the group of countries comprising Germany, France, Luxembourg, Austria, Finland, Sweden and the United Kingdom rely more on both current and past interest rate compared to consumers in Bulgaria, the Czech

3 We consider core inflation to be HICP excluding food, energy and alcohol. 
Republic, Hungary, Poland, Romania, Slovakia, Slovenia, Estonia, Latvia and Lithuania when explosive deviations in food and energy prices from other prices in the economy are taken into account. This particularly important finding regarding interest rate has implications in terms of monetary policy. In all the countries, consumers perceive higher current interest rate as an indication of higher future inflation, leading to higher inflation expectations in explosive periods. A particular policy implication of these findings is that explosive periods of headline prices from the core should be monitored closely while designing policies to anchor inflation expectations.

This study is structured as follows. Section 2 presents the methodology for explosive deviations as well as the findings. Section 3 discusses the implications in terms of inflation expectations and provides empirical findings. Section 4 reviews our findings.

\section{Methodology for Explosive Deviations, Data and Findings}

\subsection{Methodology}

\subsubsection{Right-tailed unit root tests}

There have been many attempts to develop ex-post econometric tests to detect 'rational' bubbles in the literature (see Gürkaynak, 2008, for a review). It is possible to detect exuberance by virtue of econometric techniques. Diba and Grossman (1988) were the first to propose a test to detect the explosive behaviour of rational bubbles on the stock market. They employed unit root tests by looking at the right-tail distribution and testing the unit root null against the explosive alternative. This approach is criticized by Evans (1991), who argues that unit root tests are not effective in detecting periodically collapsing bubbles. It is recognized that linear unit root tests and cointegration tests generally reject the presence of bubbles, even when they exist.

To overcome this failure of traditional testing approaches, Phillips et al. (2011) proposed an approach built upon the idea of Diba and Grossman (1988), but getting rid of the failures of running a single test. They proposed an ex-ante approach and used righttailed Augmented Dickey Fuller (ADF) tests to detect exuberance in asset price series during an inflationary phase.

This methodology is based on the standard ADF regression equation expressed as follows:

$$
\Delta y_{t}=\alpha_{r_{1}, r_{2}}+\beta_{r_{1}, r_{2}} y_{t-1}+\sum_{j=1}^{k} \psi_{r_{1}, r_{2}}^{j} \Delta y_{t-j}+\varepsilon_{t}, \varepsilon_{t} \sim i d d\left(0, \sigma_{r_{1}, r_{2}}^{2}\right)
$$

where $k$ is the lag order. $r_{1}$ and $r_{2}$ stand for the fractions of the sample. Explosive behaviour in $y_{t}$ can be tested for a shift from a random walk, i.e., the null hypothesis of a unit root in $y_{t}$ : 
$H_{0}: \beta_{r_{1}, r_{2}}=0$, against the alternative of mildly explosive behaviour $H_{1}: \beta_{r_{1}, r_{2}}>0$.

Phillips et al. (2011) proposed running the ADF test over subsets of the sample incremented by one observation at each run instead of running a single test over the whole sample period. They called this method the Supremum Augmented Dickey Fuller (SADF) test, in which the alternative hypothesis is the point of interest unlike the left-sided unit root tests. The reason why the SADF test is defined as a supremum of ADF test is that the SADF test applies the simple ADF test in a recursive manner on an increasing subsample of the whole data set, i.e., using an expanding window approach.

The SADF test sets the starting point $r_{1}$ fixed at zero. The sample size for the first regression will be $\left[\mathrm{Tr}_{\mathrm{o}}\right]$ and it will expand one observation at each run until the sequence reaches the end of the sample $\left[\operatorname{Tr}_{w}=T\right]$. Subsequently, the SADF test statistic is expressed as follows 4 :

$$
\operatorname{SADF}\left(r_{0}\right)=\sup _{r_{2} \in\left[r_{0}, 1\right]}\left\{A D F_{0}^{r_{2}}\right\}
$$

where $A D F_{0}^{r_{2}}$ represents the $\mathrm{ADF}$ test statistics for a sample that runs from 0 to $r_{2 .} r_{0}$ stands for the smallest window width fraction, whereas 1 is the largest window fraction. The fractional window size of the regression $r_{w}$ is greater than zero and related to $r_{1}$ and $r_{2}$ as follows: $r_{2}=r_{1}+r_{w}$

Phillips et al. (2011) argue that this approach can assist central bank surveillance teams and regulators due to its early warning diagnostics. Furthermore, it is claimed that this "procedure can detect market exuberance arising from a variety of sources, including mildly explosive behaviour that may be induced by changing fundamentals such as a time-varying discount factor" (Phillips et al., 2015:1045). Although this real-time bubble detection algorithm has greater power than other recursive procedures, it is realized that it may suffer from reduced power when there are multiple episodes of exuberance and collapse in the data.

Afterwards, this weakness is overcome by Phillips et al. (2015) by proposing a new method called the generalized sup ADF (GSADF) test. However, unlike the SADF, this new procedure uses flexible window widths and extends the sample coverage through changing both the start $\left(r_{1}\right)$ and the end point $\left(r_{2}\right)$ of the recursion over a flexible window range in real-time analysis, i.e., a rolling window approach. The GSADF is defined as the largest $\mathrm{ADF}$ test statistic obtained from a right-sided double recursive test over

4 For information regarding the limit distribution of the SADF test, see Phillips et al. (2014). 
all feasible ranges from $r_{1}$ to $r_{2}$ given a minimal window size $r_{0} .{ }^{5} A D F_{r 1}{ }^{2}$ is the ADF test statistics obtained from each recursive sequence, defining the supremum of this sequence. Hence, the GSADF test is expressed as follows ${ }^{6}$ :

$$
G \operatorname{SADF}\left(r_{0}\right)=\sup _{\substack{r_{2} \in\left[r_{0}, 1\right] \\ r_{1} \in\left[0, r_{2}-r_{0}\right]}}\left\{A D F_{r_{1}}^{r_{2}}\right\}
$$

In the literature, Homm and Breitung (2012) compare the power of various methods to detect bubbles. What they found is that the SADF test has the maximum power as well as being able to detect alternative forms of bubbles including that of Evans (1991). Later, Phillips et al. (2015) show through a Monte Carlo study that the GSADF test outperforms the SADF test in the presence of multiple bubbles.

\subsubsection{Date-stamping strategy}

The methodology based on recursive right-tailed ADF tests allows us to time-stamp the bubble origination and termination dates. When the null of a unit root in $y_{t}$ is rejected, the date-stamping strategy proposed by Phillips et al. (2015) is to perform SADF tests in a backward-expanding window where the endpoint of each sample is fixed at $r_{2}$ and the starting point varies from 0 to $r_{2}-r_{0}$. For a given $r_{2}$, the so-called backward sup ADF $(B S A D F)$ statistic sequence is defined as:

$$
B S A D F_{r_{2}}\left(r_{0}\right)=\sup _{r_{1} \in\left[0, r_{2}-r_{0}\right]}\left\{A D F_{r_{1}}^{r_{2}}\right\}
$$

Then, the estimated origination date of an explosive period, $r_{e}$, is defined as the first observation in which the $B S A D F$ statistic exceeds the critical value of the backward sup $A D F$ statistic:

$$
\hat{r}_{e}=\inf _{r_{2} \in\left[r_{0}, 1\right]}\left\{r_{2}: B S A D F_{r_{2}}\left(r_{0}\right)>s c u_{\left[r_{2} T\right]}^{\alpha}\right\}
$$

and the estimated termination date of explosive period, $r_{f}$, is calculated as the first observation after $r_{e}$ where the $B S A D F$ statistic falls below its critical value:

$$
\hat{r}_{f}=\inf _{r_{2} \in\left[\hat{r}_{e}, 1\right]}\left\{r_{2}: B S A D F_{r_{2}}\left(r_{0}\right)<s c u_{\left[r_{2} T\right]}^{\alpha}\right\}
$$

where $s c u_{\left[r_{2} T\right]}^{\alpha}$ is the $100(1-\alpha) \%$ critical value of the sup ADF test. $\alpha$ is the chosen level of significance.

$5 \quad$ Phillips et al. (2015) recommend choosing $r_{0}=0.01+1.8 / \sqrt{ } T$.

6 For information regarding the limit distribution of the GSADF test, see Phillips et al. (2015). 
Unlike the conventional multivariate analysis, this methodology does not necessitate the understanding of the mechanism, while yielding higher accuracy. Recursive right-sided unit root tests seem to be quite effective in detecting mildly explosive behaviour and market exuberance in data, irrespective of its origins. On the other hand, one should not come up with the expectation that this methodology predicts whether a price bubble will arise. They can, however, tell whether one has occurred.

This data-driven methodology has been applied rapidly in the literature across various areas due to its ability to identify whether there exist periods of explosive behaviour and multiple bubbles. One of the papers using the methodology and close to our study in terms of its area of interest, i.e., inflation, is by Liu et al. (2014). They have applied these recursive unit root tests to confirm the presence of inflation and to identify inflationary periods in China. This is a new perspective in that they propose judging existing inflation by identifying CPI bubbles. A CPI bubble is supposed to indicate inflationary pressure. It is argued that CPI cannot differentiate between sector-specific shocks and aggregate shocks. Furthermore, it is claimed that a great deal of high-frequency noise embodied in typical measures of inflation prevents to a great extent the detection of sustained movements in inflation, which would serve as early warning signals. ${ }^{7}$

\subsection{Data and findings for explosive behaviour}

Since we aim to examine periods where food and energy prices display explosive behaviour, we deal with relative price series, obtained by deflating headline CPI by core prices. We use monthly data for the price series covering the period from January 2003 to July 2018. Both the headline CPI and the core price index indicators for the 27 European Union (EU) member states ${ }^{8}$ are taken from Eurostat. As regards the headline CPI, we use the European Union's Harmonised Index of Consumer Prices (HICP) to make cross-country comparison possible. The core price index is the overall index excluding energy, food, alcohol and tobacco. ${ }^{9}$ For all price series, the base year is $2015 .{ }^{10}$

7 For references in the literature such as Bryan and Cecchetti (1994) and Christadoro et al. (2005), see Liu et al. (2017).

8 Belgium, Bulgaria, Czech Republic, Denmark, Germany, Estonia, Ireland, Greece, Spain, France, Italy, Cyprus, Latvia, Lithuania, Luxembourg, Hungary, Malta, the Netherlands, Austria, Poland, Portugal, Romania, Slovenia, Slovakia, Finland, Sweden and the United Kingdom.

9 Since data on the overall index excluding energy, food, alcohol and tobacco, i.e., core index for Croatia are not available on a monthly basis prior to December 2004, we do not include Croatia in the analysis.

10 See Appendix for information about data sources. 
For the full sample from January 2003 to July 2018 , the critical values are obtained from Monte Carlo simulations with 5000 replications ${ }^{11}$. The minimum window size, $r_{0}$, is chosen by the rule of thumb of Phillips et al. (2015), $r_{0}=0.01+1.8 / \sqrt{ }$. Concerning lag selection, Phillips et al. (2015) recommend applying fixed lags, Bayesian information criterion (BIC) order selection and sequential significance testing. As regards the BIC order selection, they note that the "use of BIC lag order selection satisfactorily controls size for SADF but is less adequate for GSADF where the test is oversized". The choice of a fixed lag length approach is appealing, since Phillips et al. (2012) also indicate that more sophisticated lag length selection procedures based on information criteria ${ }^{12}$ and sequential hypothesis testing ${ }^{13}$ could result in severe size distortions as well as a reduction in the power of both the SADF and GSADF tests. Furthermore, it should be noted that such procedures have higher computational costs. Hence, the fixed lag length approach is followed in this study as suggested by Phillips et al. (2015). They express that the size of the SADF and GSADF tests is reasonably well controlled when a small fixed lag length is used in the recursive tests and find having best size properties with either no or one lag. Furthermore, omitting lags overall deals with the size distortion issue as claimed by Phillips et al. (2015) that "when $k=0$ (no transient dynamics are present in the system), there are no serious size distortions in the tests". On the basis of these recommendations by Phillips et al. (2015), the test statistics are estimated using the fixed lag length of zero.

As explained in the methodology section, to identify the origination and termination dates of the explosive periods, we use the BSADF statistics of Phillips et al. (2015). Explosive periods pertaining to headline inflation deflated by core inflation have been plotted for each of the 27 European Union countries in Figure 2 in the Appendix. Figures 2a to $2 z$ ' plot the BSADF statistics against its $95 \%$ critical value sequence for the relative prices of the 27 European Union countries. Lines in the figures are the corresponding BSADF test statistics and 95\% critical values, respectively. On the basis of these statistics, we identified explosive periods in the series wherever the BSADF test statistics exceed their $95 \%$ critical value. The shaded areas identify these explosive periods. Such periods of short lengths are excluded following Phillips et al. (2015:1052). Phillips et al. (2015) recommend a minimum duration of $\log (T)$ for a bubble to exist. Hence, in our study, we neglect very short periods of exuberance and set the condition that its duration must exceed 2 months for a bubble to exist.

\footnotetext{
11 We use the Matlab computer codes accompanying Phillips et al. (2015) and provided at https://sites.google.com/site/shupingshi/home/codes to simulate consistent finite sample critical values and to get BSADF statistics.

12 Such as the Modified Information Criteria of $\mathrm{Ng}$ and Perron (2001).

13 See, for instance, $\mathrm{Ng}$ and Perron (1995).
} 
Such periods are also reported for each country in Table 1. It appears that explosive periods exist for the group of countries comprising Bulgaria, the Czech Republic, Germany, Estonia, France, Latvia, Lithuania, Luxembourg, Hungary, Austria, Poland, Romania, Slovenia, Slovakia, Finland, Sweden and the United Kingdom. On the other hand, we have not detected explosive periods for Belgium, Denmark, Ireland, Greece, Spain, Italy, Cyprus, Malta, Portugal and the Netherlands.

The results for the explosive periods reported in Table 1 reveal that the impact of global food and energy prices is quite evident for most of the countries. International food prices ${ }^{14}$ exhibited dramatic swings starting from 2007, as can be viewed in Figure 1, and the Great Drought of 2007-2008 brought about price hikes of more than 50 percent in the nominal prices of almost all food commodities, reaching its peak in June 2008. Following this spike, food prices surged again and registered their peaks in December 2010 and March 2014. All these spikes were followed by subsequent declines. World food prices displayed a more or less stable pattern after 2012, registering their final peak in March 2014 and then followed by a subsequent decline. They began to rise again after the plunge in August 2015 and reached a new plateau around September 2016 and then followed an almost stable pattern.

Energy prices, i.e., Europe Brent oil prices, go hand in hand with international food prices, as is quite apparent from Figure 1. This simultaneous rise in food and crude oil prices has raised suspicion about this close link leading to questions about a possible pass-through ${ }^{15}$. Repercussion of these developments on the behaviour of food and energy prices of the 17 EU countries that we examined can be observed quite easily.

The Great Drought period in 2007 and 2008 coincides with the explosive episodes observed in almost all the countries with the exception of Bulgaria, Slovenia and Luxembourg. The spikes recorded in world food prices in December 2010 and then in March 2014 also have reflections over the explosive periods experienced by the Czech Republic, Estonia, Bulgaria, Latvia, Lithuania, Hungary, Poland, Romania, Slovenia, Slovakia, Finland and the United Kingdom. Subsequently, shocks to both world food prices and energy prices seem to be the decisive factors in creating explosive behaviour in the headline prices with respect to core prices in those countries. It is confirmed by Parker (2017) that global energy and food prices have a considerable influence on the respective national inflation rates. Since our objective is not to give explanations

14 The FAO Food Price Index is a measure of the monthly change in international prices of a basket of food commodities. It consists of the average of five commodity group price indices, weighted with the average export shares of each of the groups for 2002-2004.

15 See Baumeister and Kilian (2014) for more evidence and discussion about this link. 
or question the reasons behind these explosive periods, we do not go into details of the country-specific dynamics here. In Sweden, Austria, France and Germany, we do not view any price spikes after 2008. For Luxembourg, there are even no spikes after 2005.

Figure 1: International Food Price Index and Europe Brent oil price

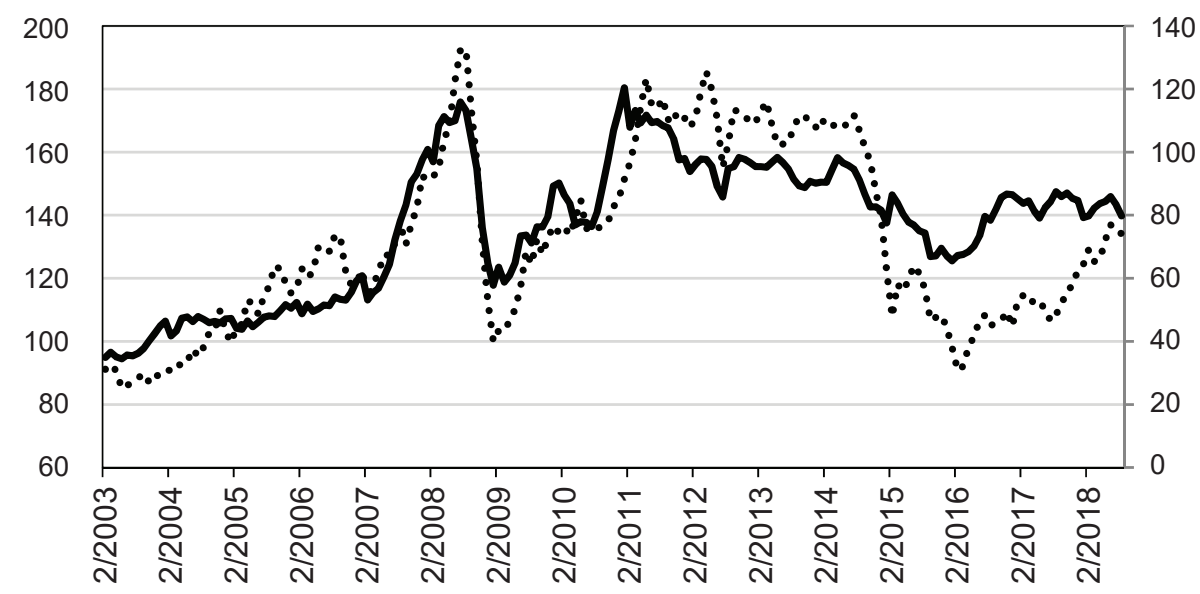

Food Price Index

...... Europe Brent Spot Price FOB (Dollars per Barrel) (right axis)

Note: The Food Price Index is the monthly real food price index (2002-2004=100) available at http://www.fao.org/worldfoodsituation/foodpricesindex/en/ and Europe Brent oil price is available at https://www.eia.gov/dnav/pet/hist/LeafHandler.ashx?n=PET\&s=RBRTE\&f=M

Source: Food and Agriculture Organization (FAO) and U.S. Energy Information Administration (EIA). 
Table 1: Date-stamping explosive periods in headline price index (deflated by core index)

\begin{tabular}{|c|c|}
\hline Country name & Origination and termination dates of explosive periods \\
\hline Bulgaria & February 2011-May 2011 \\
\hline Czech Republic & $\begin{array}{l}\text { October 2007-July 2008, January 2011-July 2011, November 2011-July 2013, } \\
\text { December 2013-June2014 }\end{array}$ \\
\hline Estonia & $\begin{array}{l}\text { June 2005-September 2005, December 2007-November 2008, December } \\
\text { 2010-July 2011, February 2012-April 2012, January 2013-March 2013, } \\
\text { January 2018-March } 2018\end{array}$ \\
\hline Latvia & $\begin{array}{l}\text { June 2006-August 2006, November 2007-July 2009, March 2010-August 2010, } \\
\text { November 2010-February } 2013\end{array}$ \\
\hline Lithuania & $\begin{array}{l}\text { February 2005-May 2005, January 2007-August 2009, } \\
\text { January 2010-September 2012, August 2015-December } 2015\end{array}$ \\
\hline Hungary & $\begin{array}{l}\text { May 2006-November 2008, February 2009-June 2009, January 2011-June 2011, } \\
\text { January 2012-June2012, November 2014-February } 2015\end{array}$ \\
\hline Poland & $\begin{array}{l}\text { November 2007-February 2008, April 2008-July 2008, February 2009-July 2009, } \\
\text { March 2010-June 2010, January 2011-June 2011, January 2012-June } 2012\end{array}$ \\
\hline Romania & July 2008-September 2008, January 2011-June 2011, April 2018-June 2018 \\
\hline Slovenia & January 2012-May 2012, July 2012-October 2012, January 2013-March 2013 \\
\hline Slovakia & $\begin{array}{l}\text { March 2006-June 2006, April 2008-June 2008, January 2011-June 2011, } \\
\text { December 2015-May 2016, July 2016-November } 2016\end{array}$ \\
\hline Finland & $\begin{array}{l}\text { March 2006-June 2006, April 2008-June 2008, January 2011-June 2011, } \\
\text { December 2015-May 2016, July 2016-November } 2016\end{array}$ \\
\hline Sweden & June 2008- August 2008 \\
\hline Austria & November 2007-August 2008 \\
\hline Luxembourg & July 2005-October 2005 \\
\hline France & April 2008-July 2008 \\
\hline Germany & June 2005-November 2005, April 2006-July 2006, April 2008-July 2008 \\
\hline United Kingdom & $\begin{array}{l}\text { July 2005-October 2005, April 2006-June 2007, November 2007-August 2009, } \\
\text { January 2010-April 2010, January 2011-April } 2012\end{array}$ \\
\hline
\end{tabular}

Note: Since we set the condition following Phillips et al. (2015) that for a bubble to exist, its duration must exceed 2 months, we have not detected any explosive period for Portugal, Belgium, Denmark, Ireland, Greece, Spain, Italy, Cyprus, Malta and the Netherlands.

Source: The authors calculation. 


\section{Empirical Model for the Implications of Explosiveness on Consumers' Inflation Expectations and Findings}

\subsection{Empirical model}

There exists some extant literature on how expectations are formed and respond to changes in the policy regime. The traditional macroeconomics textbook approach is to assume that everyone shares a common information set on the basis of which their expectations are formed. Nonetheless, the fact that there might be disagreement among people about expectations, which also displays substantial variation over time, is generally ignored. This failure is overcome by Mankiw and Reis (2002) by introducing a "sticky-information" model with disagreement at its very heart. In this model, rational and forward-looking agents update their expectations only periodically due to costly information, thereby giving rise to inflation persistence.

Mankiw et al. (2004) explore whether this model is able to predict the disagreement observed in survey data. Their findings suggest that agents do not fully incorporate all past inflation information. These "sticky-information" expectations are influenced by macro-economic variables, while recent macroeconomic data are not adequately incorporated in inflation expectations. More than that, in their analysis as regards to whether the survey data are consistent with adaptive expectations, they conclude that "observed inflation expectations are consistent with neither the sophistication of rational expectations nor the naiveté of adaptive expectations" irrespective of the sources of survey data used (Mankiw et al., 2004). Correspondingly, their findings reveal that inflation expectations are not updated instantly but partially and incompletely in response to macroeconomic news, suggesting an updating scheme that occurs in a staggered manner. Finally, it should be mentioned that their analysis implies that disagreement will vary with macroeconomic conditions.

\subsubsection{Benchmark regression}

Our ultimate concern is to get a better insight into how consumers' inflation expectations change in response to explosive increases of food and energy prices relative to other prices in the economy. On that account, together with the purpose of getting a benchmark specification for inflation expectations, we have adopted the model of inflation expectations proposed by Mankiw et al. (2004) as our baseline specification.

In order to get a notion of whether the survey data are in line with adaptive expectations, the specification proposed by Mankiw et al. (2004) is the following:

Adaptive expectations: $E_{t} \pi_{t+12}=\alpha+\beta(L) \pi_{t}+\gamma U_{t}+\kappa U_{t-3}+\delta i_{t}+\phi i_{t-3}$ 
where $E_{t} \pi_{t+12}$ represents one-year ahead consumers' inflation expectation, $\pi_{t}$ is inflation and $L$ is the lag operator, $U_{\mathrm{t}}$ is unemployment and $i_{\mathrm{t}}$ is interest rate.

Mankiw et al. (2004) reject the adaptive expectations hypothesis that $H_{0}: \gamma=\kappa=\delta=\phi=0$. In other words, consumers do not rely only on past information about inflation. Furthermore, consumers do not fully incorporate all of the past information about inflation since $\beta(1)<1$.

\subsubsection{Specification incorporating explosive periods}

In order to incorporate the change in expectations during explosive periods of deviations in relative prices, we use the setup suggested by Arora et al. (2013), which is obtained by modifying the model of Mankiw et al. (2004). On the basis of the information obtained in the previous section regarding explosive deviations in relative prices, we introduce dummy variables to capture these explosive periods as in Arora et al. (2013). In other words, the dummy variable $D_{t}$ will take the value of 1 when there is an explosive deviation and zero otherwise. Date-stamping of explosive periods is explained in detail in the previous section together with the findings related to explosive behaviour of food and energy prices.

$$
\begin{aligned}
& E_{t} \pi_{t+12}=\alpha+\beta(L) \pi_{t}+\gamma U_{t}+\kappa U_{t-3}+\delta i_{t}+\phi i_{t-3}+\alpha^{\prime} D_{t}+\beta(L)^{\prime} D_{t} \pi_{t}+\gamma^{\prime} D_{t} U_{t}+ \\
& +\kappa^{\prime} D_{t} U_{t-3}+\delta^{\prime} D_{t} i_{t}+\phi^{\prime} D_{t} i_{t-3}+\varepsilon_{t}
\end{aligned}
$$

The lagged inflation term $(\beta(1)<1)$ represents inflationary persistence. Regarding past inflation, we have included observed annual inflation for each of the previous three months ${ }^{16}$.

\subsection{Data, methodology and findings for inflation expectations}

Given the explosive periods detected in the previous section, the analysis performed here is based on the idea of getting implications for inflation expectations. On the account that we have detected notable explosive periods only for 17 out of the $27 \mathrm{EU}$ countries, the analysis of inflation expectations is executed only for those countries, i.e., Bulgaria, the Czech Republic, Germany, Estonia, France, Latvia, Lithuania, Luxembourg, Hungary, Austria, Poland, Romania, Slovenia, Slovakia, Finland, Sweden and the United Kingdom.

First, we run the regressions for the whole sample of the countries, i.e., for the $17 \mathrm{EU}$ countries. Then, in order to make a comparison among different groups of countries, we

16 Estimation results of models (2) and (3) are not sensitive to the lag selection of the inflation variable. 
divided the full sample into two sub-samples. One of the sub-samples includes the Central and Eastern European Countries (CEECs) ${ }^{17}$ comprising Bulgaria, the Czech Republic, Estonia, Hungary, Latvia, Lithuania, Poland, Romania, Slovakia, and Slovenia. The second group contains the rest of the countries in the full sample of 17 European countries, i.e., Germany, France, Luxembourg, Austria, Finland, Sweden and the United Kingdom.

Panel regression estimations are implemented using monthly data from January 2004 to July $2018^{18}$. Inflation expectations data are based on consensus forecasts exploiting the quantitative data on inflation expectations from the European Commission's Consumer Survey ${ }^{19}$. The rate of inflation is calculated using the Harmonised Index of Consumer Prices (HICP) from Eurostat and the base year is 2015. Unemployment rate series are harmonised unemployment rates (\%) and also taken from Eurostat. Interest rates are 3-month money market interest rates taken from Eurostat if available. In cases where it is not provided by Eurostat, we have taken 3-month or 90-day interbank rates from Federal Reserve Bank of St. Louis's Federal Reserve Economic Data (FRED). ${ }^{20}$

The Mankiw adaptive expectations baseline model (2) and our proposed model (3) involving explosive periods are estimated using panel data and including fixed-effects. Following Mankiw et al. (2004) and Arora et al. (2013), we test for the null hypothesis of adaptive expectations, i.e., whether consumers solely rely on past inflation information when forming inflation expectations. The alternative hypothesis includes the impacts of macroeconomic information coming from unemployment and interest rate. We run this test independently for both normal and explosive periods.

Table 2 reports the estimation results for the whole sample, while Tables 3 and 4 give the results for the country sub-samples. On the basis of the estimation results presented in Tables 2, 3 and 4, regarding the baseline model (2), in normal periods, we reject the null hypothesis of adaptive expectations, i.e., $H_{0}: \gamma=\kappa=\delta=\phi=0$, for the whole sample and the sub-sample groups. Hence, we can conclude that consumers in all the countries take macroeconomic variables such as unemployment and interest rate into

17 Central and Eastern European Countries (CEECs) is an OECD term for the group of countries including Albania, Bulgaria, Croatia, the Czech Republic, Hungary, Poland, Romania, Slovakia, Slovenia, and the three Baltic States: Estonia, Latvia and Lithuania. In our sample, we do not include Albania and Croatia (https://stats.oecd.org/glossary/detail.asp?ID=303). Croatia has been excluded due to data availability restrictions in the previous section. Albania is not included in our whole sample of $27 \mathrm{EU}$ countries, hence the analysis here excludes Albania.

18 On the basis of data availability and annual percentage changes considered for the inflation variable, we start the analysis from January 2004.

19 Micro data set collected by the European Commission in the context of the Harmonised EU Programme of Business and Consumer Surveys (https://www.econstor.eu/ obitstream/10419/22228/1/dpsfb200313.pdf).

20 See Table 5 in the Appendix for information about data sources. 
account as well as past inflation when forming inflation expectations in normal periods. The signs of the coefficients are in line with the results obtained in Mankiw et al. (2004). Hence, we find robust evidence that consumers' inflation expectations quite coincide with the adaptive expectations proposed by Mankiw et al. (2004).

Likewise, on the basis of the estimation results regarding model (3) in Tables 2, 3 and 4 , we again reject the adaptive expectations hypothesis in both normal and explosive periods. This indicates that consumers rely on past inflation, as well as information coming from current and past macroeconomic variables during explosive periods when forming inflation expectations. Findings related to model (3) also indicate that dummy variables of the explosive period are jointly significant, rejecting the null hypothesis in Tables 2, 3 and 4, giving evidence for the influence of explosive periods on inflation expectation formation.

When we analyse in detail the expectation formation, test results tell us that past inflation information significantly affects consumers' expectations again in all country groups, while particular differences exist related to this impact between the two groups of countries in normal and explosive periods. Furthermore, agents do not fully incorporate all past information on inflation $(\beta(1)<1)$.

Particularly, consumers rely less on past inflation when they observe explosive deviation in food and energy prices compared to other prices in the economy for the group of countries in Table 3, i.e., for the CEECs (Bulgaria, the Czech Republic, Estonia, Latvia, Lithuania, Hungary, Poland, Romania, Slovenia and Slovakia). For instance, for the CEECs in Table 3, the overall effect of past inflation on inflation expectation is 0.081 , which is lower than that in normal periods. On the other hand, the impact of past inflation on inflation expectations does not change in explosive periods for the group of countries in Table 4 (Germany, France, Luxembourg, Austria, Finland, Sweden and the United Kingdom). That is to say, consumers do not adjust their expectations on the basis of past inflation during explosive phases. Hence, consumers in these two groups of countries behave differently in response to explosiveness in food and energy prices.

The estimation results also suggest that macroeconomic information influences inflation expectations and that impact changes over explosive periods. When explosive periods are taken into account, for the CEECs, overall positive and significant coefficients of current and past interest rates imply that consumers perceive higher interest rates as an indication of higher future expected inflation, leading to higher inflation expectations (Table 3). During explosive periods, consumers change and update their inflation expectations on the basis of information coming from interest rate. On the other hand, they do not make such an adjustment on the basis of information on unemployment rate during explosive periods. The test results suggest that lower current unemployment rate regarded as a signal of increasing economic activity leads to higher inflation expectations in normal periods, 
while that impact on inflation expectations does not change in response to explosive deviations in food and energy prices.

Regarding the group of countries in Table 4, when the explosive periods are accounted for, higher past and lower current unemployment rate raises inflation expectations. These impacts get stronger during explosive periods compared to normal periods. Furthermore, higher current interest rate and lower past interest rate raise inflation expectations when the overall impact is accounted for. Consumers change their inflation expectations on the basis of information coming from unemployment rate and interest rate during explosive periods.

When a comparison is made between the two groups of countries, the overall impact of current interest rate (0.321) is much more pronounced in Germany, France, Luxembourg, Austria, Finland, Sweden and the United Kingdom than in the CEECs.

As a consequence, consumers in the CEECs adjust their inflation expectations by taking into account both the interest rate and past inflation during explosive phases, while those in the other group of countries make adjustment in their inflation expectations on the basis of information coming from macroeconomic indicators such as interest rate and unemployment rate when food and energy prices deviate from other prices in the economy explosively. In other words, inflation expectations change during explosive periods for all the countries. 
Table 2: Modelling inflation expectations (whole sample ${ }^{\curlyvee}$ )

Dependent variable: one-year ahead inflation expectations

\begin{tabular}{|c|c|c|}
\hline & Mankiw Baseline Model (2) & Model (3) \\
\hline \multicolumn{3}{|l|}{ Past inflation } \\
\hline$\beta(1)$ : sum of 3 coefficients & $\begin{array}{l}0.194^{* * *} \\
(0.007)\end{array}$ & $\begin{array}{l}0.218^{* * *} \\
(0.008)\end{array}$ \\
\hline \multicolumn{3}{|l|}{ Unemployment } \\
\hline$\gamma^{\prime}:$ date of forecast & $\begin{array}{c}-0.425^{* * *} \\
(0.025)\end{array}$ & $\begin{array}{l}-0.338^{* * *} \\
(0.031)\end{array}$ \\
\hline$\kappa: 3$ month prior & $\begin{array}{l}0.437^{* * *} \\
(0.025)\end{array}$ & $\begin{array}{l}0.359 * * * \\
(0.031)\end{array}$ \\
\hline \multicolumn{3}{|l|}{ Interest rate } \\
\hline$\delta:$ date of forecast & $\begin{array}{l}0.115^{* * *} \\
(0.017)\end{array}$ & $\begin{array}{l}0.174^{* * *} \\
(0.022)\end{array}$ \\
\hline$\varphi: 3$ month prior & $\begin{array}{c}-0.092^{* * *} \\
(0.016)\end{array}$ & $\begin{array}{l}-0.164^{* * *} \\
(0.020)\end{array}$ \\
\hline \multicolumn{3}{|l|}{ Dummy*Past inflation } \\
\hline$\beta(1)^{\prime}$ : sum of 3 coefficients & - & $\begin{array}{c}-0.092^{* * *} \\
(0.014)\end{array}$ \\
\hline \multicolumn{3}{|l|}{ Dummy*Unemployment } \\
\hline$\gamma^{\prime}:$ date of forecast & - & $\begin{array}{l}-0.111^{* *} \\
(0.056)\end{array}$ \\
\hline$\kappa^{\prime}: 3$ month prior & - & $\begin{array}{l}0.067 \\
(0.055)\end{array}$ \\
\hline \multicolumn{3}{|l|}{ Dummy*Interest Rate } \\
\hline$\delta^{\prime}:$ date of forecast & - & $\begin{array}{l}-0.137^{* * *} \\
(0.036)\end{array}$ \\
\hline$\varphi^{\prime}: 3$ month prior & - & $\begin{array}{l}0.169 * * * \\
(0.036)\end{array}$ \\
\hline
\end{tabular}

Reject adaptive expectations?

\begin{tabular}{|c|c|c|}
\hline (i) Normal periods $\mathbf{s}^{(1)}$ & $\mathrm{F}(4,2896)=90.33^{* * *}$, Yes & $F(4,2888)=60.77^{* * *}$, Yes \\
\hline (ii) Explosive periods ${ }^{(2)}$ & - & $\mathrm{F}(8,2888)=42.88^{* * *}$, Yes \\
\hline Joint significance (Dummies) & - & $\mathrm{F}(8,2888)=12.57^{* * *}$ \\
\hline
\end{tabular}

Notes: 'rCountries: Bulgaria, the Czech Republic, Germany, Estonia, France, Latvia, Lithuania, Luxembourg, Hungary, Austria, Poland, Romania, Slovenia, Slovakia, Finland, Sweden and the United Kingdom. $* * * * * *$ represent statistical significance at the $1 \%, 5 \%$ and $10 \%$ respectively.

(1) $H_{0}: \gamma=\kappa=\delta=\phi=0$; (2) $H_{0}: \gamma=\kappa=\delta=\phi=\gamma^{\prime}=\kappa^{\prime}=\delta^{\prime}=\phi^{\prime}=0$.

Period of analysis: January 2004-July 2018

Source: The Author's calculations 
Table 3: Modelling inflation expectations (group of countries ${ }^{\curlyvee}$ )

\begin{tabular}{|c|c|c|}
\hline \multicolumn{3}{|c|}{ Dependent variable: one-year ahead inflation expectations } \\
\hline & Mankiw Baseline Model (2) & Model (3) \\
\hline \multicolumn{3}{|l|}{ Past inflation } \\
\hline$\beta(1)$ : sum of 3 coefficients & $\begin{array}{l}0.184^{* * *} \\
(0.008)\end{array}$ & $\begin{array}{l}0.207^{* * *} \\
(0.010)\end{array}$ \\
\hline \multicolumn{3}{|l|}{ Unemployment } \\
\hline$\gamma^{\prime}:$ date of forecast & $\begin{array}{l}-0.406^{* * *} \\
(0.029)\end{array}$ & $\begin{array}{l}-0.339 * * * \\
(0.036)\end{array}$ \\
\hline$\kappa: 3$ month prior & $\begin{array}{l}0.419 * * * \\
(0.029)\end{array}$ & $\begin{array}{l}0.368^{* * *} \\
(0.035)\end{array}$ \\
\hline \multicolumn{3}{|l|}{ Interest rate } \\
\hline$\delta:$ date of forecast & $\begin{array}{l}0.073^{* * *} \\
(0.020)\end{array}$ & $\begin{array}{l}0.124^{* * *} \\
(0.026)\end{array}$ \\
\hline$\varphi: 3$ month prior & $\begin{array}{l}-0.049 * * * \\
(0.019)\end{array}$ & $\begin{array}{l}-0.111^{* * *} \\
(0.023)\end{array}$ \\
\hline \multicolumn{3}{|l|}{ Dummy*Past inflation } \\
\hline$\beta(1)^{\prime}:$ sum of 3 coefficients & - & $\begin{array}{l}-0.126^{* * *} \\
(0.017)\end{array}$ \\
\hline \multicolumn{3}{|l|}{ Dummy*Unemployment } \\
\hline$r:$ date of forecast & - & $\begin{array}{l}-0.069 \\
(0.063)\end{array}$ \\
\hline$\kappa^{\prime}: 3$ month prior & - & $\begin{array}{l}-0.020 \\
(0.063)\end{array}$ \\
\hline \multicolumn{3}{|l|}{ Dummy*Interest Rate } \\
\hline$\delta^{\prime}:$ date of forecast & - & $\begin{array}{l}-0.119 * * * \\
(0.041)\end{array}$ \\
\hline$\varphi^{\prime}: 3$ month prior & $\begin{array}{l}- \\
-\end{array}$ & $\begin{array}{l}0.146^{* * *} \\
(0.041)\end{array}$ \\
\hline
\end{tabular}

\section{Reject adaptive expectations?}

\begin{tabular}{l|c|l}
\hline (i) Normal periods $^{(1)}$ & $F(4,1700)=57.09 * *$, Yes & $F(4,1692)=38.51^{* * *}$, Yes \\
\hline (ii) Explosive periods $\mathbf{s}^{(2)}$ & - & $F(8,1692)=30.60^{* * *}$, Yes \\
\hline Joint significance (Dummies) & - & $F(8,1692)=15.82^{* * *}$ \\
\hline
\end{tabular}

Notes: ${ }^{r}$ Countries: Bulgaria, the Czech Republic, Estonia, Latvia, Lithuania, Hungary, Poland, Romania, Slovenia and Slovakia.

***, *** * represent statistical significance at the $1 \%, 5 \%$ and $10 \%$ respectively.
(1) $H_{0}: \gamma=\kappa=\delta=\phi=0$
(2) $H_{0}: \gamma=\kappa=\delta=\phi=\gamma^{\prime}=\kappa^{\prime}=\delta^{\prime}=\phi^{\prime}=0$.

Period of analysis: January 2004 - July 2018

Source: The Author's calculations 
Table 4: Modelling inflation expectations (group of countries')

\begin{tabular}{|c|c|c|}
\hline \multicolumn{3}{|c|}{ Dependent variable: one-year ahead inflation expectations } \\
\hline & Mankiw Baseline Model (2) & Model (3) \\
\hline \multicolumn{3}{|l|}{ Past inflation } \\
\hline$\beta(1)$ : sum of 3 coefficients & $\begin{array}{l}0.312^{* * *} \\
(0.015)\end{array}$ & $\begin{array}{l}0.320^{* * *} \\
(0.017)\end{array}$ \\
\hline \multicolumn{3}{|l|}{ Unemployment } \\
\hline$r:$ date of forecast & $\begin{array}{l}-0.350 * * * \\
(0.069)\end{array}$ & $\begin{array}{l}-0.294^{* * *} \\
(0.074)\end{array}$ \\
\hline$\kappa: 3$ month prior & $\begin{array}{l}0.313^{* * *} \\
(0.069)\end{array}$ & $\begin{array}{l}0.267^{* * *} \\
(0.075)\end{array}$ \\
\hline \multicolumn{3}{|l|}{ Interest rate } \\
\hline$\delta:$ date of forecast & $\begin{array}{l}0.530 * * * \\
(0.043)\end{array}$ & $\begin{array}{l}0.559 * * * \\
(0.047)\end{array}$ \\
\hline$\varphi: 3$ month prior & $\begin{array}{l}-0.530 * * * \\
(0.044)\end{array}$ & $\begin{array}{l}-0.565^{* * *} \\
(0.048)\end{array}$ \\
\hline \multicolumn{3}{|l|}{ Dummy*Past inflation } \\
\hline$\beta(1)^{\prime}:$ sum of 3 coefficients & - & $\begin{array}{c}0.036 \\
(0.045)\end{array}$ \\
\hline \multicolumn{3}{|l|}{ Dummy*Unemployment } \\
\hline$\gamma:$ date of forecast & $\begin{array}{l}- \\
-\end{array}$ & $\begin{array}{c}-0.409 * * \\
(0.204)\end{array}$ \\
\hline$\kappa^{\prime}: 3$ month prior & $\begin{array}{l}- \\
-\end{array}$ & $\begin{array}{l}0.470 * * \\
(0.204)\end{array}$ \\
\hline \multicolumn{3}{|l|}{ Dummy*Interest Rate } \\
\hline$\delta^{\prime}:$ date of forecast & - & $\begin{array}{c}-0.238^{* *} \\
(0.118)\end{array}$ \\
\hline$\varphi^{\prime}: 3$ month prior & $\begin{array}{l}- \\
-\end{array}$ & $\begin{array}{l}0.338^{* * *} \\
(0.119)\end{array}$ \\
\hline
\end{tabular}

\section{Reject adaptive expectations?}

\begin{tabular}{l|c|c}
\hline (i) Normal periods $^{(1)}$ & $\mathrm{F}(4,1189)=68.34^{* * *}$, Yes & $\mathrm{F}(4,1181)=57.57^{* * *}$, Yes \\
\hline (ii) Explosive periods $^{(2)}$ & - & $\mathrm{F}(8,1181)=35.45^{* *}$, Yes \\
\hline Joint significance (Dummies) & - & $\mathrm{F}(8,1181)=3.85^{* * *}$ \\
\hline
\end{tabular}

Notes: ${ }^{\gamma}$ Countries: Germany, France, Luxembourg, Austria, Finland, Sweden and the United Kingdom. $* * * * *, *$ represent statistical significance at the $1 \%, 5 \%$ and $10 \%$ respectively.

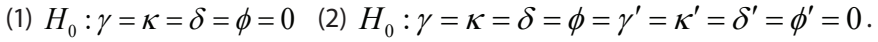

Period of analysis: January 2004 - July 2018

Source: The author's calculations. 


\section{Conclusion}

Determining a certain tendency towards explosive behaviour on a market, if it exists, gives policymakers vital information to mitigate the pressure on prices. This information gains more significance if consumers revise their inflation expectations in the face of explosive increases, posing difficulty in anchoring consumer inflation expectations, which play an essential role for the monetary policy. Inspired with these ideas in this study, we explore the periods of explosive deviations in headline inflation from the core for the $27 \mathrm{EU}$ countries using a recent methodology developed by Phillips et al. (2015). The evidence indicates that such periods are present for $17 \mathrm{EU}$ countries over the period from January 2003 to July 2018. It is observed that these explosive episodes mostly coincide with shocks to international food and energy prices. When these periods are examined in terms of their influence on consumers' inflation expectations, it is realized that consumers rely both on past inflation and information coming from macroeconomic variables such as interest rate and unemployment rate when forming inflation expectations during normal and explosive periods. On the other hand, consumers behave differently in two groups of countries while adjusting their inflation expectations during explosive periods. Particularly, consumers in the group of countries comprising Bulgaria, the Czech Republic, Estonia, Latvia, Lithuania, Hungary, Poland, Romania, Slovenia and Slovakia rely less on past inflation during explosive periods. Furthermore, consumers in these countries change and update their inflation expectations on the basis of information coming from interest rate during explosive phases. On the other hand, consumers in Germany, France, Luxembourg, Austria, Finland, Sweden and the United Kingdom do not make any adjustment in their inflation expectations on the basis of past inflation during explosive periods. It should be mentioned that for the latter group of countries, the impact of macroeconomic variables such as unemployment rate and interest rate on consumers' inflation expectations changes during explosive periods compared to normal periods.

An even more important finding is that consumers' expectations change during explosive periods. In other words, periods when headline inflation deviates from core inflation explosively are taken into account when forming inflation expectations. This behavioural change in inflation expectations during explosive periods necessitates close monitoring of food and energy prices while designing policies to anchor inflation expectations. This is particularly important regarding interest rate, which has implications in terms of monetary policy as well. In all the countries, consumers perceive higher current interest rate as an indication of higher future inflation, leading to higher inflation expectations in explosive periods. This impact is much more pronounced in Germany, France, Luxembourg, Austria, Finland, Sweden and the United Kingdom than in the CEECs. A particularly important monetary policy implication of these findings is that periods of explosive deviations in food and energy prices relative to other prices in the economy should be monitored closely while designing policies to anchor inflation expectations. 


\section{APPENDIX}

Table 5: Variable definitions and sources

\begin{tabular}{|c|c|c|}
\hline Variable name & Definition & Source \\
\hline $\begin{array}{l}\text { Inflation } \\
\text { expectations }\end{array}$ & $\begin{array}{l}\text { One-year ahead consumers' inflation } \\
\text { expectation, consumer inflation } \\
\text { perceptions }\end{array}$ & $\begin{array}{l}\text { European Commission Consumer Survey } \\
\text { of Expectations available on } \\
\text { https://ec.europa.eu/info/busi- } \\
\text { ness-economy-euro/indicators-sta- } \\
\text { tistics/economic-databases/ } \\
\text { business-and-consumer-surveys/down- } \\
\text { load-business-and-consumer-survey-da- } \\
\text { ta/time-series_en }\end{array}$ \\
\hline $\begin{array}{l}\text { Harmonised } \\
\text { consumer price } \\
\text { inflation }\end{array}$ & $\begin{array}{l}\text { Annual headline inflation rate calculat- } \\
\text { ed from } \operatorname{HICP}(2015=100)\end{array}$ & $\begin{array}{l}\text { Eurostat, https://ec.europa.eu/eurostat/ } \\
\text { data/database }\end{array}$ \\
\hline Core price index & $\begin{array}{l}\text { Overall index excluding energy, food, } \\
\text { alcohol and tobacco, HICP }(2015=100)\end{array}$ & $\begin{array}{l}\text { Eurostat, https://ec.europa.eu/eurostat/ } \\
\text { data/database }\end{array}$ \\
\hline $\begin{array}{l}\text { Unemployment } \\
\text { rate }\end{array}$ & $\begin{array}{l}\text { Harmonised unemployment } \\
\text { rates }(\%), \text { percentage of active } \\
\text { population, seasonally adjusted data, } \\
\text { unemployment according to ILO } \\
\text { definition }\end{array}$ & $\begin{array}{l}\text { Economic Research, Federal Reserve Bank } \\
\text { of St. Louis } \\
\text { https://fred.stlouisfed.org/ and } \\
\text { Eurostat, https://ec.europa.eu/eurostat/ } \\
\text { data/database }\end{array}$ \\
\hline Interest rate & $\begin{array}{l}\text { 3-month or } 90 \text {-day rates and yields: } \\
\text { interbank rates or } 3 \text {-month money } \\
\text { market interest rates }\end{array}$ & $\begin{array}{l}\text { Economic Research, Federal Reserve Bank } \\
\text { of St. Louis } \\
\text { https://fred.stlouisfed.org/ and } \\
\text { Eurostat, https://ec.europa.eu/eurostat/ } \\
\text { data/database }\end{array}$ \\
\hline
\end{tabular}

Source: Author. 
Figure 2: Explosive periods in headline price index (deflated by core index)

Figure 2a: Estonia

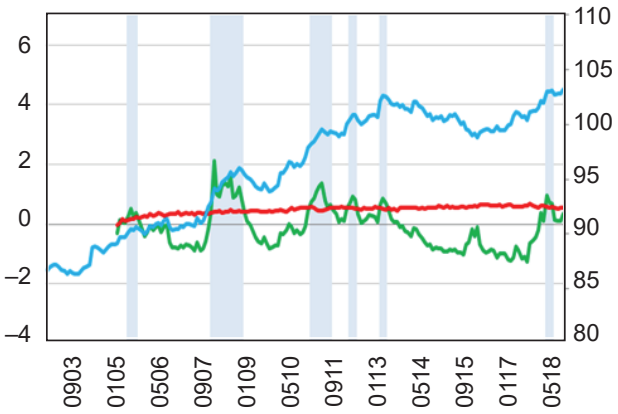

Figure 2c: Bulgaria

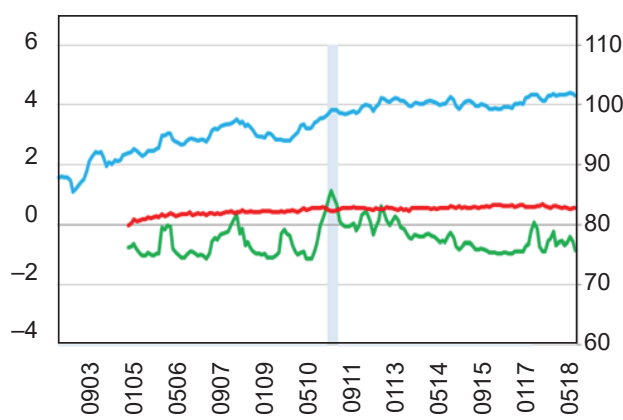

Figure 2e: Slovakia

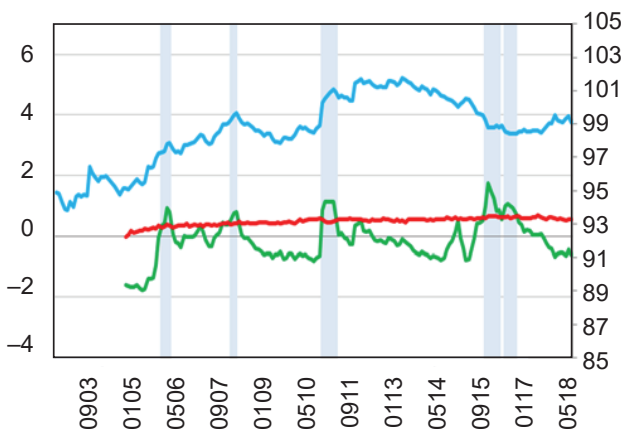

Figure 2b: Latvia

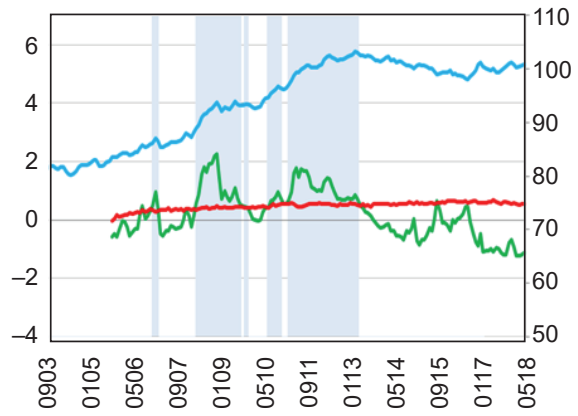

Figure 2d: Czech Republic

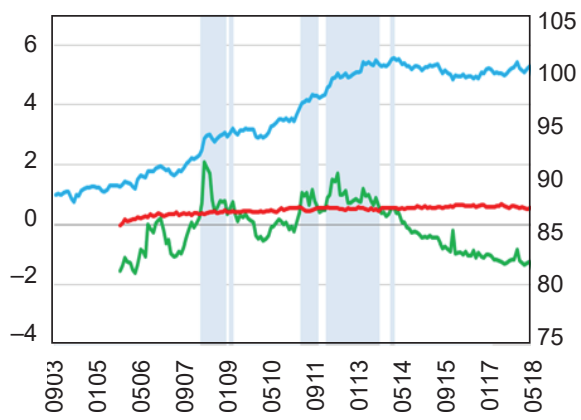

Figure 2f: Lithuania

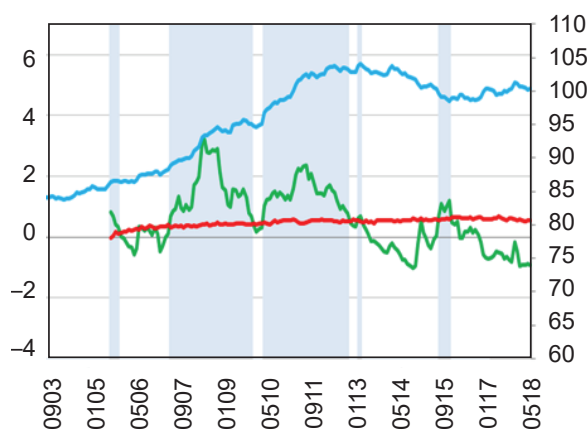

- Backwards SADF sequence (left axis)

- $95 \%$ ctitical value sequence (left axis)

- Country (right axis) 


\section{Figure 2 (Continuation)}

Figure 2g: Hungary

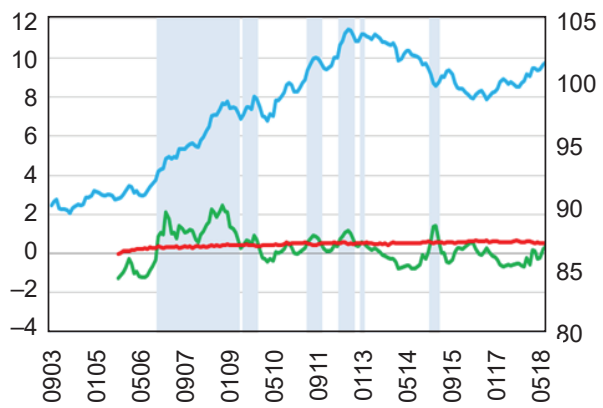

Figure 2i: Romania

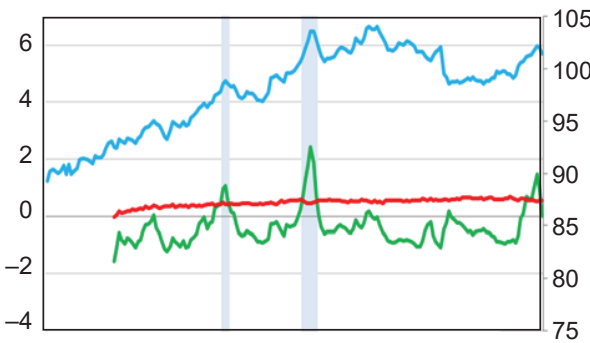

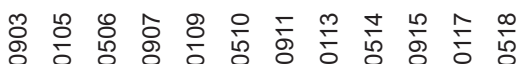

Figure 2h: Poland

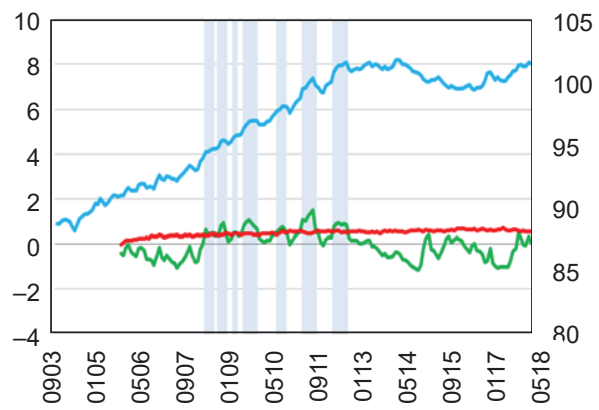

Figure 2k: United Kingdom

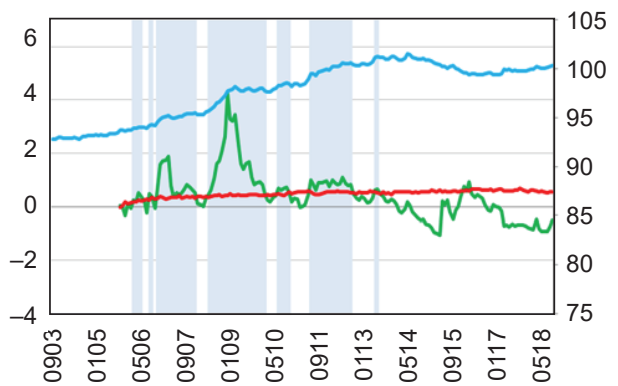

Figure 2j: Slovenia

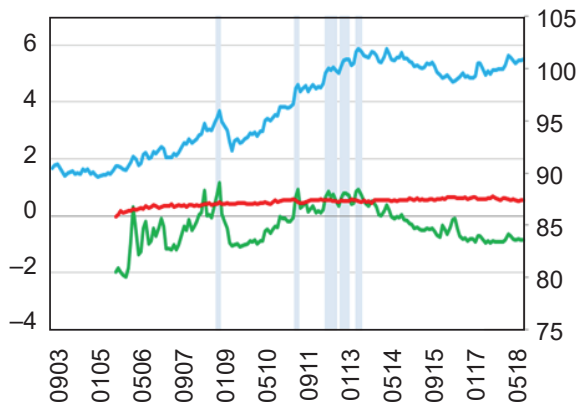

Figure 2l: Sweden

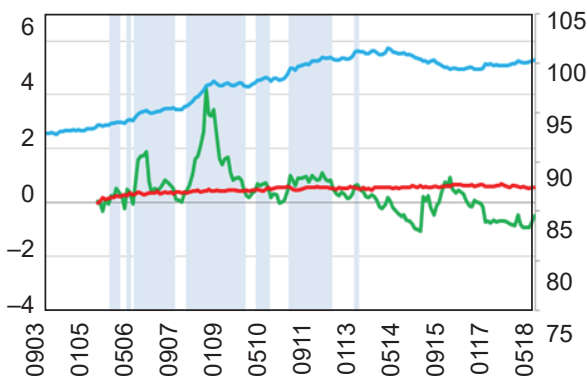

\footnotetext{
- Backwards SADF sequence (left axis)

- $95 \%$ ctitical value sequence (left axis)

- Country (right axis)
} 


\section{Figure 2 (Continuation)}

Figure 2m: Finland

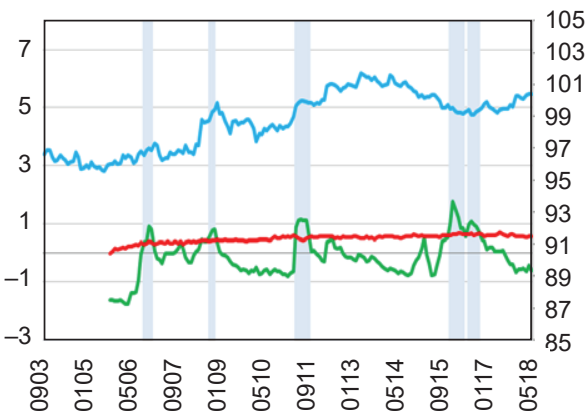

Figure 20: Germany

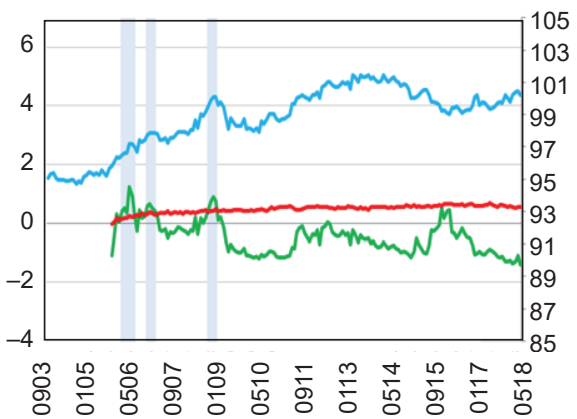

Figure 2q: Portugal

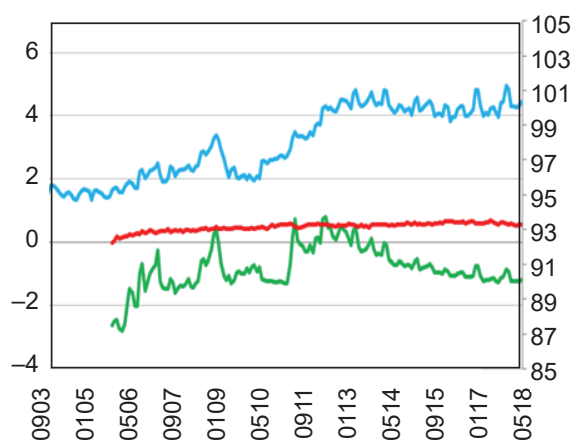

Figure 2n: Austria

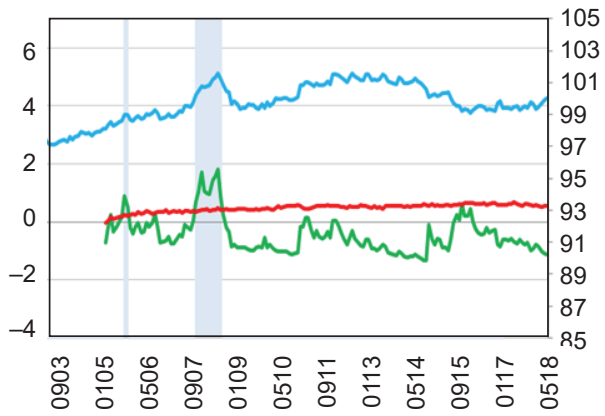

Figure 2p: France

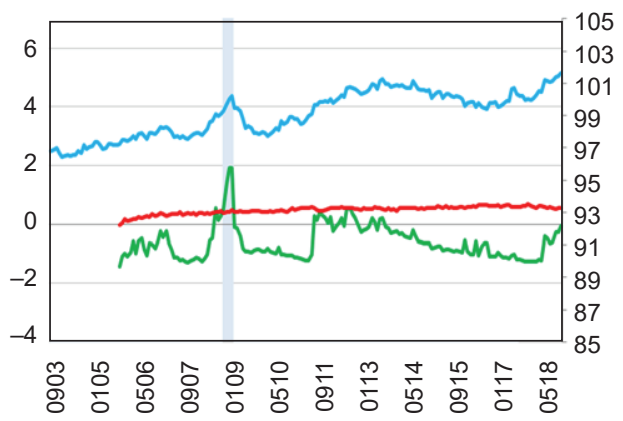

Figure 2r: Ireland

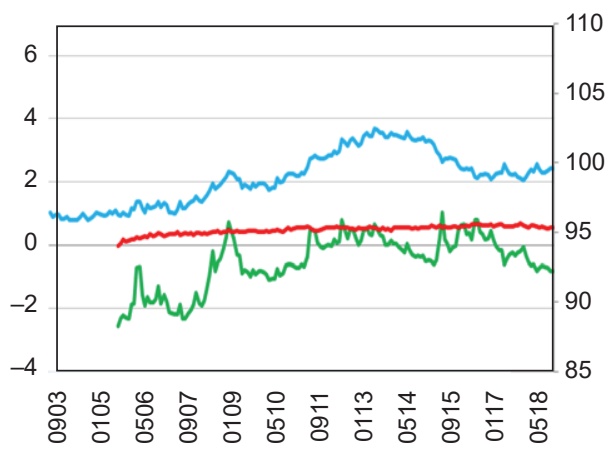




\section{Figure 2 (Continuation)}

Figure 2s: Netherlands

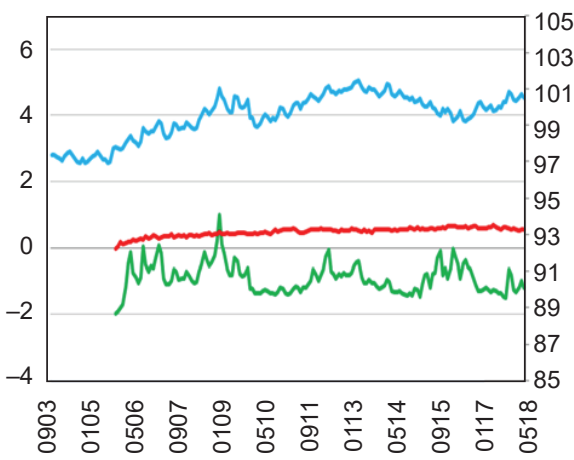

Figure 2u: Denmark

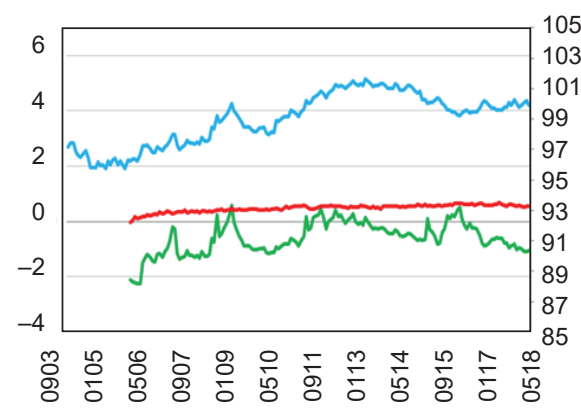

Figure 2w: Cyprus

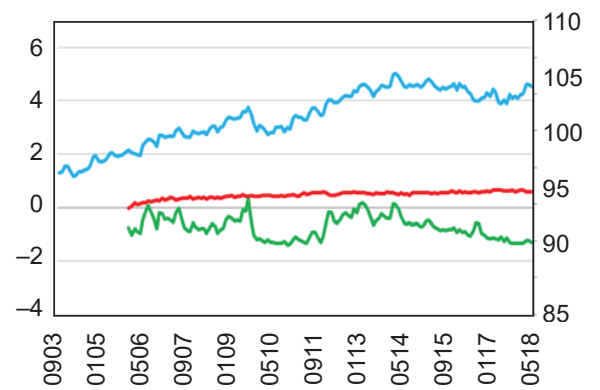

Figure 2t: Spain

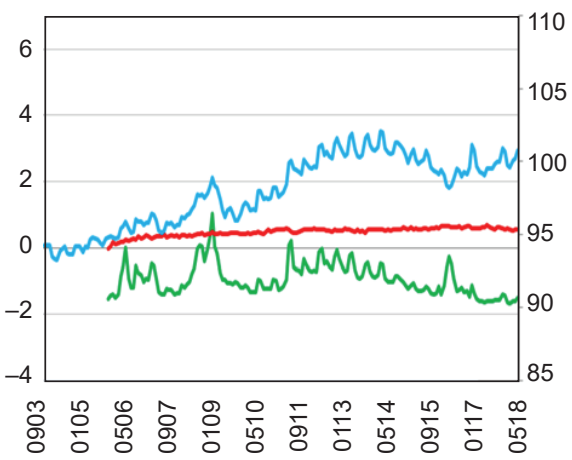

Figure 2v: Malta

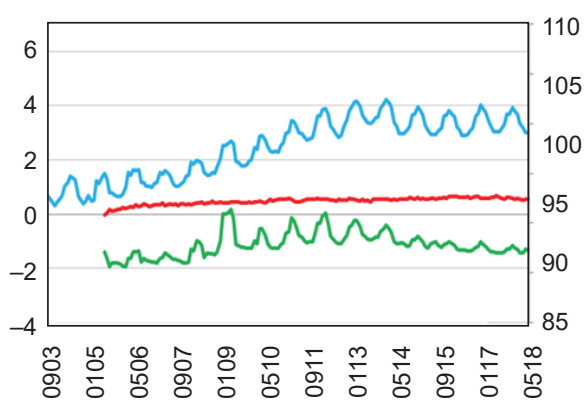

Figure 2x: Belgium

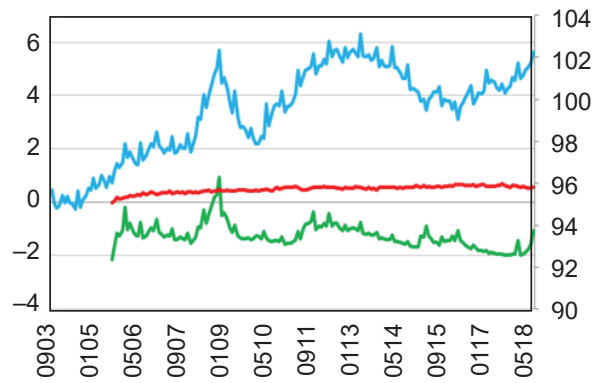

- Backwards SADF sequence (left axis)

- $95 \%$ ctitical value sequence (left axis)

- Country (right axis) 


\section{Figure 2 (Continuation)}

Figure 2y: Italy

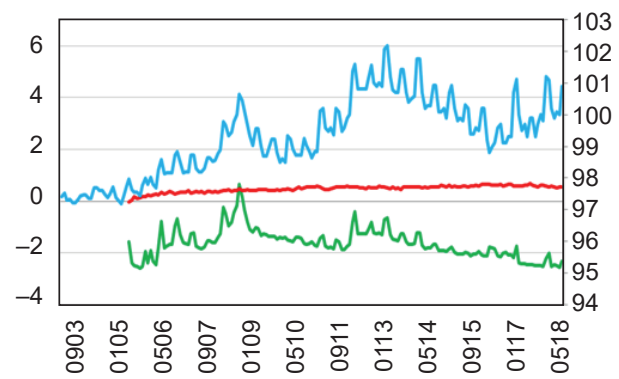

Figure 2z': Luxembourg

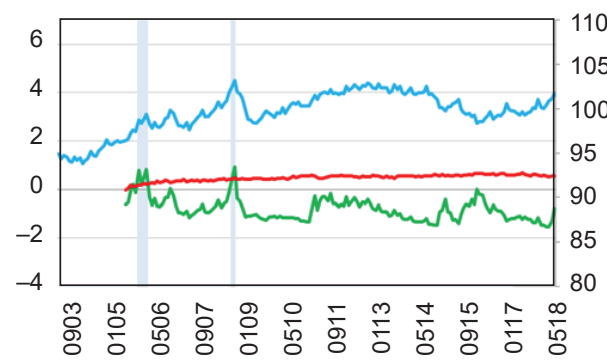

Backwards SADF sequence (left axis)
$-95 \%$ ctitical value sequence (left axis)
Country (right axis)
Figure 2z: Greece

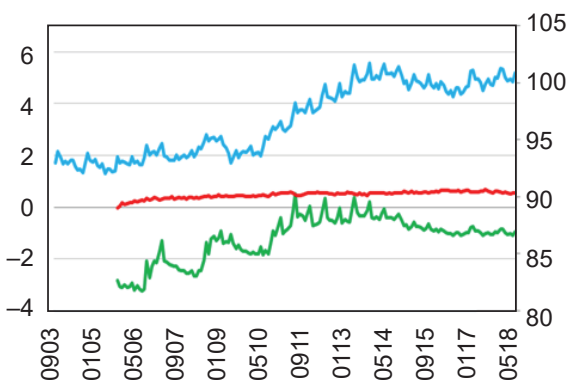

Source: The Author's calculations. 


\section{References}

Arora V., Gomis-Porqueras P., Shi S., 2013. "The divergence between core and headline inflation: Implications for consumers' inflation expectations", Journal of Macroeconomics, 38, 497-504.

Bullard, J., 2011. "Measuring inflation: the core is rotten". https://files.stlouisfed.org/files/ htdocs/publications/review/11/07/bullard.pdf

Baumeister C., Kilian L. 2014. "Do oil price increases cause higher food prices?", Economic Policy, 29 (80), 691-747, https://doi.org/10.1111/1468-0327.12039

Diba, B. T., Grossman, H. I., 1988. "Explosive rational bubbles in stock prices?", The American Economic Review, 78(3), 520-530.

Evans, G., 1991. "Pitfalls in testing for explosive bubbles in asset prices", American Economic Review, 81, 922-930.

Gürkaynak R., 2008. “Econometric Tests of Asset Price Bubbles: Taking Stock”, Journal of Economic Surveys, 22, 166-186.

Homm, U., Breitung J., 2012. "Testing for speculative bubbles in stock markets: a comparison of alternative methods", Journal of Financial Econometrics, 10 (1), 198-231.

Liu T.Y., Chang H.L., Su C.W., Lobont O.R., 2017. "Is there inflation in China? Evidence by a unit root approach", International Review of Economics and Finance, article in press. https://doi.org/10.1016/j.iref.2017.01.011

Mankiw, G.N., Reis, R., 2002. "Sticky information versus sticky prices: a proposal to replace the New Keynesian Phillips curve", Quarterly Journal of Economics, 117 (4), 1295-1328.

Mankiw, G.N., Reis, R., Wolfers, J., 2004. “Disagreement about inflation expectations”, NBER Macroeconomics Annual 2003, 209-248.

Ng, S., Perron P., 1995. "Unit Root Tests in ARMA Models with Data-Dependent Methods for the Selection of the Truncation Lag", Journal of the American Statistical Association, 90, 268-281.

Ng, S., Perron P., 2001. “Lag Length Selection and the Construction of Unit Root Tests with Good Size and Power", Econometrica, 69, 1519-1554.

Parker M., 2017. "Global inflation: the role of food, housing and energy prices", ECB Working Paper, No. 2024

Phillips, P. C. B., Wu, Y., Yu, J., 2011. “Explosive behaviour in the 1990s NASDAQ: When did exuberance escalate asset values?", International Economic Review, 52(1), 201-226

Phillips, P. C. B., Shi S., Yu, J., 2014. "Specification sensitivity in right-tailed unit root testing for explosive behaviour", Oxford Bulletin of Economics and Statistics, 76(3):315-333.

Phillips, P. C. B., Shi, S. P., Yu, J., 2015. “Testing for multiple bubbles: Historical Episodes of Exuberance and Collapse in the S\&P 500", International Economic Review, 56(4), 1043-1078

Thornton, D.L., 2011. “Core versus Headline Inflation: An Opportunity for Greater Transparency", Economic Synopses, Federal Reserve Bank of St. Louis 